\title{
PENGEMBANGAN EKONOMI LOKAL KABUPATEN MALANG MELALUI KAJIAN POTENSI KLASTER INDUSTRI KECIL
}

\author{
Arini Fitria Mustapita ${ }^{1}$ \\ Afi Rachmat Slamet ${ }^{2}$
}

Fakultas Ekonomi dan Bisnis Universitas Islam Malang, Jawa Timur, Indonesia ${ }^{1,2}$

Email: AriniMustapita@unisma.ac.id

\begin{abstract}
Local Economic Development: Small Industry Cluster: Location Quotient analysis and Klassen's typology. This study aims to (i) To map the types of small industries which are potential to be developed in Malang Regency (ii) Formulate the right strategy for developing potential industrial clusters in Malang Regency. This study uses secondary data obtained from BPS Malang Regency and Malang Regency Industry and Trade Agency. The analytical method used is contribution analysis, Location Quotient analysis and Klassen's typology. Contribution Analysis shows the average contribution to the Province of East Java is 5.88\%. This result is not much different from the contribution of Malang Regency, where the biggest contribution is still the same, namely the processing industry by $29.28 \%$. The LQ analysis continued, showing that there are six sectors that have a $L Q$ value of more than 1 , which means that it is a base sector and has the potential to be developed. The sectors include agriculture, processing industry, water supply, construction, wholesale trade and other services. Whereas typology Klassen with the results of the developed sector and growing rapidly is in the agricultural sector, processing industry and other services.
\end{abstract}

Keywords: Local Economic Development: Small Industry Cluster: Location Quotient analysis and Klassen's typology.

\begin{abstract}
Abstrak: Pengembangan Ekonomi Lokal, Klaster Industri Kecil, Location Quotient analysis dan Tipologi Klassen. Penelitian ini bertujuan untuk (i) Memetakan jenis-jenis industri kecil apa saja yang potensial untuk dikembangkan di Kabupaten Malang (ii) Merumuskan strategi yang tepat untuk pengembangan klaster industri yang potensial di Kabupaten Malang. Penelitian ini menggunakan data sekunder yang diperoleh dari BPS Kab Malang dan Disperindag Kab Malang. Metode analisis yang digunakan adalah analisis kontribusi, analisis Location Quotient dan juga tipologi klassen. Analisis Kontribusi menunjukkan Rata-rata kontribusi untuk Provinsi Jawa Timur sebesar 5,88\% hasil ini tidak berbeda jauh dengan kontribusi Kabupaten Malang, dimana kontribusi terbesarnya masih tetap sama yaitu industri pengolahan sebesar 29,28\%. Dilanjutkan Analisis LQ yang menunjukkan terdapat enam sektor yang memiliki nilai LQ lebih dari 1 yang artinya merupakan sektor basis dan memiliki potensi untuk dikembangkan. Sektor tersebut antara lain adalah sektor pertanian, industri pengolahan, pengadaan air, konstruksi, perdagangan besar dan jasa lainnya. Sedangkan tipologi klassen dengan hasil sektor maju dan tumbuh dengan pesat berada pada sektor pertanian, industri pengolahan dan jasa lainnya.
\end{abstract}

Kata Kunci: Pengembangan Ekonomi Lokal, Klaster Industri Kecil, Location Quotient analysis dan Tipologi Klassen. 


\section{PENDAHULUAN}

Indonesia sebagai negara sedang berkembang dihadapkan pada suatu tuntutan untuk melaksanakan pembangunan di segala bidang secara merata, terutama pembangunan ekonomi. Pembangunan di bidang ekonomi dapat mendukung pencapaian tujuan serta mendorong perubahan-perubahan atau pembaharuan bidang kehidupan lainnya. Oleh karena itu tidak mengherankan apabila pembangunan ekonomi menjadiperhatianutama.

Pertumbuhan ekonomi dan prosesnya yang berkelanjutan merupakan kondisi utama bagi kelangsungan pembangunan ekonomi daerah. Karena pada umumnya pertumbuhan ekonomi dijadikan sebagai tolak ukur untuk melihat perkembangan yang terjadi dalam proses kegiatan ekonomi dan merupakan indikasi untuk mengukur sejauh mana keberhasilan suatu kebijakan yang dilaksanakan oleh pemerintah. Perekonomian suatu negara bisa dikatakan berhasil apabila kegiatan ekonominya lebih tinggi daripada yang dicapai pada masa sebelumnya serta perkembangan kegiatan perekonomian yang menyebabkan barang dan jasa yang diproduksi dalam masyarakat bertambah (Sukirno, 2011). Sedangkan kondisi
Indonesia dengan jumlah penduduk yang terus bertambah artinya kebutuhan ekonomi juga ikut bertambah, sehingga dibutuhkan penambahan pendapatan setiap tahun. Penambahan pendapatan dapat dilihat dari peningkatan output agregat (barang dan jasa) atau Produk Domestik Regional Bruto (PDRB) pada setiap tahunnya (Tambunan, 2001). Secara makro pertumbuhan dan peningkatan PDRB dari tahun ke tahun merupakan indikator dari keberhasilan pembangunan daerah yang dapat dikategorikan dalam berbagai sektor ekonomi, antara lain yaitu (1) sektor pertanian; (2) pertambangan dan penggalian; (3) industri pengolahan; (4) listrik dan air minum; (5) bangunan dan konsturksi; 6) perdagangan, hotel dan restoran; (7) pengangkutan dan komunikasi; (8) keuangan, persewaan dan jasa perusahaan, dan (9) jasa-jasa. Kabupaten Malang sendiri memiliki Produk Domestik Regional Bruto atas dasar harga konstan menurut lapangan usaha, dimana secara rata-rata terjadi kenaikan dari tahun ke tahun. Hal tersebut dapat dilihat pada Tabel 1 yang menunjukkan peningkatan dari tahun 2014 dengan nilai sebesar 52.550.417,04 hingga pada tahun 2018 dengan nilai sebesar 64.823.281,55. 
Tabel 1.

Produk Domestik Regional Bruto Kabupaten Malang Atas Dasar Harga Konstan 2010 Menurut Lapangan Usaha (juta rupiah), 2014 -2018 (Tabel Dinamis)

\begin{tabular}{|c|c|c|c|c|c|c|}
\hline & Kategori & 2014 & 2015 & 2016 & 2017 & 2018 \\
\hline 1. & $\begin{array}{l}\text { Pertanian, Kehutanan, dan } \\
\text { Perikanan }\end{array}$ & 9224600.88 & 9542355.95 & 9826908.15 & 9994064.97 & 9799582.33 \\
\hline 2. & $\begin{array}{l}\text { Pertambangan dan } \\
\text { Penggalian }\end{array}$ & 1097424.29 & 1129469.08 & 1144314.96 & 1202920.15 & 1240932.43 \\
\hline 3. & Industri Pengolahan & 15548409.52 & 16549375.19 & 17556286.55 & 18550567.18 & 19914527.83 \\
\hline 4. & Pengadaan Listrik dan Gas & 53332.52 & 52939.07 & 55209.75 & 58477.33 & 61550.60 \\
\hline 5. & $\begin{array}{l}\text { Pengadaan Air, Pengelolaan } \\
\text { Sampah, Limbah dan Daur } \\
\text { Ulang }\end{array}$ & 52808.06 & 55828.63 & 58583.77 & 62621.93 & 66370.62 \\
\hline 6. & Konstruksi & 6319594.28 & 6562571.22 & 6898982.75 & 7384119.27 & 7926514.27 \\
\hline 7. & $\begin{array}{l}\text { Perdagangan Besar dan } \\
\text { Eceran; Reparasi }\end{array}$ & 10065934.33 & 10597951.19 & 11196122.42 & 11979767.07 & 12781846.34 \\
\hline 8. & $\begin{array}{l}\text { Transportasi dan } \\
\text { Pergudangan }\end{array}$ & 566540.11 & 610036.86 & 653281.56 & 705547.51 & 765531.30 \\
\hline 9. & $\begin{array}{l}\text { Penyediaan Akomodasi dan } \\
\text { Makan Minum }\end{array}$ & 1671284.44 & 1783320.58 & 1913585.28 & 2071216.56 & 2253820.79 \\
\hline 10. & Informasi dan Komunikasi & 2518364.02 & 2689109.10 & 2877388.91 & 3085628.42 & 3324147.50 \\
\hline 11. & $\begin{array}{l}\text { Jasa Keuangan dan } \\
\text { Asuransi }\end{array}$ & 851567.89 & 901218.75 & 956207.31 & 983900.80 & 1032120.33 \\
\hline 12. & Real Estate & 755523.78 & 800477.44 & 849482.95 & 895151.16 & 965241.49 \\
\hline 13. & Jasa Perusahaan & 191456.80 & 207788.07 & 219775.36 & 231810.26 & 249871.50 \\
\hline 14. & $\begin{array}{l}\text { Administrasi Pemerintahan, } \\
\text { Pertahanan }\end{array}$ & 977459.37 & 1026230.07 & 1066304.35 & 1086497.17 & 1132890.59 \\
\hline 15. & Jasa Pendidikan & 1256997.12 & 1347626.61 & 1429171.50 & 1491654.87 & 1578889.21 \\
\hline 16. & $\begin{array}{l}\text { Jasa Kesehatan dan } \\
\text { Kegiatan Sosial }\end{array}$ & 311924.99 & 324970.40 & 340867.95 & 360718.74 & 388061.22 \\
\hline \multirow[t]{2}{*}{17.} & Jasa Lainnya & 1087194.65 & 1136553.29 & 1204871.34 & 1264265.80 & 1341383.21 \\
\hline & PDRB & 52550417.04 & 55317821.50 & 58247344.86 & 61408929.19 & 64823281.55 \\
\hline
\end{tabular}

Sumber: Data BPS 2020

Peningkatan PDRB dapat digunakan

dalam melihat proses lajunya pertumbuhan Regional Bruto Kabupaten Malang selama ekonomi suatu daerah, sehingga tingkat periode2014-2018 atas dasarhargakonstantahun perkembangan PDRB per kapita seringkali 2000yang terlihat pada Tabel 1. Yang didominasi digunakan sebagai ukuran kesuksesan oleh sektor industri pengolahan. Namun suatu daerah dalam mencapai cita-cita demikian secara persentase pola perkembangan untuk menciptakan pembangunan ekonomi. sempat mengalami penurunan. Oleh karena 
itu untuk menstabilkan pertumbuhan sektor bekerja secara kolektif dalam menciptakan suatu industri pengolahan perlu dilakukan suatu upaya kondisi yang lebih baik untuk pertumbuhan yaitu dengan pengembangan ekonomi lokal. ekonomi daerah dan penciptaan kesempatan

Pengembangan ekonomi lokal lapangan kerja. Pengembangan ekonomi lokal merupakan usaha daerah dalam memacu menyediakan cukup banyak alternatif program pembangunan ekonomi dan diharapkan atau kegiatan yang dapat dipilih sebagai prioritas dapat memberikan manfaat bagi masyarakat dalam mendorong pengembangan ekonomi keseluruhan secara luas (Bappenas, 2004). lokal di daerah salah satunya mendorong Pengembangan ekonomi lokal sendiri pertumbuhan klaster (Bappenas, 2004). merupakan penumbuhan suatu lokalitas Pratomo (2008) menjelaskan secara lebih mandiri dengan menggunakan klaster merupakan pengelompokan berbagai potensi kekuatan lokal, sumber daya manusia, perusahaan pada sektor usaha yang sama kelembagaan dan fisik dengan upaya yang dalam suatu wilayah tertentu. Suatu klaster ditumbuh kembangkan masyarakat lokal itu terdiri dari industri inti, industri terkait, sendiri (tumbuh jiwa kewiraswastaan lokal) industri pendukung dan jasa lainnya yang untuk mengorganisasi serta mentransformasi pengembangannya tidak difokuskan pada potensi-potensi ini menjadi penggerak bagi perusahaan inti saja namun secara keseluruhan. pembangunan lokal sehingga tercipta kondisi Kunci keberlanjutan pengembangan klaster yang lebih baik dengan pertumbuhan lapangan yaitu terciptanya kerjasama antar stakeholder pekerjaan, dan meningkatkan kualitas hidup dan efisiensi kolektif yang dapat dilakukan untuk seluruh masyarakat (Bappenas, 2004). pada semua lini tahapan produksi mulai dari Tujuan dari pembangunan ekonomi penyediaan input, produk, proses produksi, lokal adalah membangun potensi ekonomi pemasaran dan distribusi hingga ke konsumen yang ada di suatu daerah tertentu untuk akhir. Jalinan kerjasama dalam lingkungan meningkatkan keadaan ekonomi dan kualitas usaha klaster memberikan manfaat positif hidup untuk semua di masa depan. Dalam proses dengan menciptakan rantai nilai produksi yang ini masyarakat, dan mitra dari sektor swasta saling menguntungkan sehingga produktivitas 
usaha dapat ditingkatkan. Pendekatan klaster Sektor Basis dan Non Basis di Kabupaten diharapkan mampu memberikan solusi untuk Gorontalo. Dari ke tujuh sektor basis Kabupaten meningkatkan daya saing industri di daerah. Gorontalo, sektor Pengadaan Listrik dan Gas Klaster industri adalah sejumlah perusahaan merupakan sektor yang paling stabil untuk dan lembaga yang terkonsentrasi pada suatu wilayah, serta saling berhubungan dalam bidang yang khusus dan mendukung persaingan. Klaster tidak hanya dibangun dari hadirnya industri, tetapi industri harus saling terhubung berdasarkan rantai nilai (Lestari, 2010).

Secara empiris, penelitin mengenai pengembangan ekonomi lokal melalui kajian potensi klaster industri kecil untuk menentukan sektor yang potensial untuk dikembangkan telah banyak dilakukan dan menunjukkan hasil yang berbeda tiap masing-masing daerah.

Penelitian Mukhlis dkk., (2014) data time series PDRB Kota Bandar Lampung meneliti mengenai Pengembangan Ekonomi dan Provinsi Lampung Tahun 2000-2012.. Lokal Kota Palembang dengan menggunakan pendekatan Tipologi Klassen. Berdasarkan hasil perhitungan LQ diperoleh beberapa UKM yang memiliki nilai LQ lebih besar dari yaitu dari sektor logam, mesin, kimia, dan aneka industry, selanjutnyasektorhasilpertanian dan peternakan, serta sektor hasil hutan dan perkebunan.

Penelitian Jumiyanti (2018) mengenai Analisis Location Quotient dalam Penentuan dijadikan kegiatan basis di wilayah Kabupaten Gorontalo. Dengan kontribusi yang cukup tinggi dan juga nilai LQ Kabupaten Gorontalo terhadap perekonomian Provinsi Gorontalo yang juga cukup tinggi menjadikan kegiatan ini sebagai kegiatan basis yang sangat baik untuk dikembangkan karena banyak sekali dampak positif yang ditimbulkan dari sektor ini. Penelitian Endi (2015) menganalisis tentang Analisis Sektor Unggulan dan Pengembangan Wilayah di Kota Bandar Lampung 2000-2012. Menggunakan variabel Hasil untuk menentukan sektor yang maju dan tumbuh pesat, basis, dan kompetitif maka sektor/sub/sub-sub sektor ekonomi yang akan masuk dalam kategori sektor ekonomi yaitu (1) Sektor Industri Pengolahan dan (2) Sektor Keuangan, real esta,jasa perusahaan. Berdasarkan latar belakang dan rumusan masalah, maka penelitian ini bertujuan untuk 1) memetakan jenis-jenis industri kecil 
apa saja yang potensial untuk dikembangkan di Kabupaten Malang 2) Merumuskan strategi yang tepat untuk pengembangan klaster industri yang potensial di Kabupaten Malang Berdasarkan latar belakang dan rumusan masalah, maka penelitian ini bertujuan untuk: (1) memberi kontribusi berupa analisis sektor mana saja yang potensial untuk dikembangkan (2) menjelaskan strategi yang dapat digunakan dalam pengembangan ekonomi lokal pada sektor yang potensial.

\section{METODE PENELITIAN}

Penelitian ini merupakan kajian industri yang membahas mengenai identifikasi potensi industri kecil dan menengah yang ada di kabupaten Malang berdasarkan keunggulan serta lokasi dan jenis industri kecil dan menengah tahun 2014-2018. Data yang digunakan adalah data sekunder yang diperoleh dari berbagai instansi terkait seperti Badan Pusat Statistik Kabupaten Malang, Jawa Timur, Departemen Perindustrian dan Perdagangan Kabupaten Malang. Selain itu data juga diperoleh melalui studi pustaka dari berbagai literature berupa teks, jurnal, dan sumber lain yang berhubungan dengan permasalahan yang dibahas.
Dalam menentukan jenis industri kecil dan menengah yang memiliki potensi maka alat analisis yang digunakan adalah: 1) Analisis Kontribusi, 2) Analisis Location Quotient, dan 3) Analisis Tipologi Klassen.

Analisis Kontribusi digunakan untuk melihat peranan/kontribusi sektor industri kecil dan menengah di Kabupaten Malang terhadap Pendapatan Regional Kabupaten Malang. Lalu kontribusi industri kecil dan menengah Kabupaten Malang terhadap industri kecil dan menengah Provinsi Jawa Timur. Kontribusi sektor industri kecil terhadap pendapatan regional Kabupaten Malang (Sjafrizal, 2016):

$\mathrm{K}_{\mathrm{IKM}}=\left[\frac{N_{I K M i}}{\sum P D R B}\right] \times 100$

Kontribusi sektor industri kecil dan menengah Kabupaten Malang terhadap nilai industrikecil dan menengah Provinsi Jawa Timur:

$\mathrm{S}_{\mathrm{IKM}}=\left[\frac{N_{I K M i} N_{I K M i}}{N_{I K M j} N_{I K M j}}\right] \times 100$

Analisis Location Quotient adalah suatu perbandingan tentang besarnya peranan suatu sektor/industri di suatu daerah terhadap besarnya peranan sektor/industri tersebut pada suatu daerah yang lebih luas. Formulasi analisis LQ adalah sebagai berikut (Warpani, 2001): 
$L Q=\frac{V_{i(s)} / V_{(s)}}{V_{i(r)} / V_{(r)}}$

Analisis tipologi klassen adalah salah satu alat anaisis yang digunakan untuk mengetahui klasifikasi sektor perekonomian daerah Kabupaten Malang. Sebagai dasar menentukan sektor-sektor unggulan untuk dilakukan pengelompokan digunakan kombinasi pertumbuhan dan kontribusi tiap-tiap sub sektor di masing-masing wilayah pengamatan.

Tabel 2. Klasifikasi sektor PDRB menurut Tipologi Klassen

\begin{tabular}{|c|c|c|}
\hline $\begin{array}{l}\text { Laju } \\
\text { Pertumbuhan/ } \\
\text { Kontribusi }\end{array}$ & $\mathrm{Si}>\mathrm{S}$ & $\mathrm{Si}<\mathrm{S}$ \\
\hline $\mathrm{Ski}>\mathrm{Sk}$ & $\begin{array}{c}\text { Kuadran I } \\
\text { Sektor } \\
\text { Industri Cepat } \\
\text { Tumbuh dan } \\
\text { Cepat Maju }\end{array}$ & $\begin{array}{c}\text { Kuadran II } \\
\text { Sektor } \\
\text { Industri } \\
\text { Berkembang } \\
\text { Cepat }\end{array}$ \\
\hline $\mathrm{Ski}<\mathrm{Sk}$ & $\begin{array}{c}\text { Kuadran III } \\
\text { Sektor } \\
\text { Industri Cepat } \\
\text { Maju Tapi } \\
\text { Tertekan } \\
\end{array}$ & $\begin{array}{c}\text { Kuadran IV } \\
\text { Sektor } \\
\text { Industri } \\
\text { Relatif } \\
\text { Tertinggal } \\
\end{array}$ \\
\hline
\end{tabular}

Sumber: Sjafrizal (2008)

\section{HASIL DAN PEMBAHASAN}

Potensi UKM di Kabupaten Malang. Rata-rata kontribusi UKM terhadap Produk Domestik Regional (PDRB) Kabupaten Malang pada tahun 2018 adalah sebesar 5,91 \%. Kelompok UKM yang memiliki kontribusi terbesar berada pada kelompok UKM dari sektor industri pengolahan sebesar $29,48 \%$, perdagangan besar sebesar 19,5\%, pertanian sebesar 17,3\% dan konstruksi sebesar 12,03\%. Berdasarkan hasil kontribusi tersebut diharapkan UKM dari sektor-sektor tersebut dapat terus berkembang dan berperan dalam mengembangkan ekonomi lokal Kabupaten Malang, namun juga tetap memperhatikan peranan UKM dari sektor-sektor lainnya.

Hasil dari Tabel 3 menunjukkan kontribusi UKM berdasar sektor ekonomi di Kabupaten Malang dan Provinsi Jawa Timur dengan rata-rata kontribusi untuk Provinsi Jawa Timur sebesar 5,88\% hasil ini tidak berbeda jauh dengan kontribusi Kabupaten Malang, dimana kontribusi terbesarnya masih tetap sama yaitu industri pengolahan sebesar 29,28\%.

Kontribusi sektor pertanian terhadap PDRB Kabupaten Malang menurun dikarenakan sektor pertanian masih berbasis onfarm (peningkatan produksi) belum berorientasi terhadap peningkatan nilai tambah melalui diversifikasi hasil pertanian dan perkebunan. Peningkatan nilai tambah ini mempengaruhi revenue ratio ( $\mathrm{RC}$ ratio) petani yang artinya biaya produksi yang petani keluarkan lebih 
Tabel 3.

Perbandingan Kontribusi UKM bedasar Sektor Ekonomi di Kabupaten Malang dan Provinsi Jawa Timur, 2018

\begin{tabular}{llcccc}
\hline No & \multicolumn{2}{c}{ SEKTOR EKONOMI } & \multicolumn{2}{c}{ Kontribusi \% } & \multicolumn{2}{c}{ LQ } \\
\cline { 2 - 5 } & & $\begin{array}{c}\text { Kab } \\
\text { Malang }\end{array}$ & Jawa Timur & Kab Malang & Basis/Non Basis \\
\hline 1. & Pertanian & 17,32 & 11,77 & 1,44 & Basis \\
2. & Pertambangan & 2,07 & 5,15 & 0,36 & Non Basis \\
3. & Industri Pengolahan & 29,48 & 29,38 & 1,03 & Basis \\
4. & Pengadaan Listrik & 0,10 & 0,33 & 0,31 & Non Basis \\
5. & Pengadaan Air & 0,10 & 0,10 & 1,04 & Basis \\
6. & Konstruksi & 12,03 & 9,20 & 1,30 & Basis \\
7. & Perdagangan Besar & 19,50 & 18,34 & 1,07 & Basis \\
8. & Transportasi & 1,12 & 2,93 & 0,39 & Non Basis \\
9. & Penyediaan Akomodasi & 3,29 & 5,17 & 0,63 & Non Basis \\
10. & Informasi dan Komunikasi & 4,91 & 5,61 & 0,88 & Non Basis \\
11. & Jasa Keuangan & 1,65 & 2,57 & 0,62 & Non Basis \\
13. & Real Estate & 1,49 & 1,72 & 0,86 & Non Basis \\
14. & Jasa Perusahaan & 0,38 & 0,78 & 0,49 & Non Basis \\
15. & Administrasi Pemerintah & 1,86 & 2,23 & 0,81 & Non Basis \\
16. & Jasa Pendidikan & 2,48 & 2,63 & 0,92 & Non Basis \\
17. & Jasa Kesehatan & 0,61 & 0,65 & 0,89 & Non Basis \\
18. & Jasa Lainnya & 2,12 & 1,45 & 1,44 & Basis \\
\hline & Rata-Rata & $\mathbf{5 , 9 1}$ & $\mathbf{5 , 8 8}$ & & \\
\hline
\end{tabular}

Sumber: Data Diolah 2020

kecil dibanding keuntungan yang didapat. di Kabupaten Malang. Dimana dengan Nilai revenue ratio ( $\mathrm{RC}$ ratio) inilah yang meningkatnya sektor industri secara tidak mempengaruhi Nilai Tukar Petani (NTP). langsungakanmeningkatkan sektorperdagangan Beberapa kendala yang dihadapi petani antara serta daya beli masyarakat. Sedangkan untuk lain panjangnya mata rantai perdagangan besarnya nilai kontribusi masih berfluktuasi sampai konsumen, sehingga pembagian margin mengingat sektor industri sangat dipengaruhi keuntungan tidak berpihak pada petani. pada beberapa hal, diantaranya kebijakan Selanjutnya adalah sektor industri pemerintah di sektor industri, tingkat inflasi, pada Kabupaten Malang cukup memberikan serta standar kualitas produk industri sehingga kontribusi terhadap keseluruhan PDRB memiliki daya saing dalam menghadapi Kabupaten Malang. Karena bagaimanapun Masyarakat Ekonomi Asean (MEA) yang sektor industri merupakan salah satu sektor diterapkan mulai tahun 2015. penggerak roda perekonomian masyarakat 
Keberadaan dan Peran Industri Kecil peranan suatu sektor/industri di Kabupaten terhadap Perekonomian Wilayah Kabupaten Malang terhadap besarnya peranan sektor/ Malang. Dalam menganalisis peranan suatu industri tersebut pada Provinsi Jawa Timur. sektor pada suatu wilayah hingga dapat diketahui Terdapat enam sektor yang memiliki nilai LQ potensi ekonomi suatu wilayah berdasarkan lebih dari 1 yang artinya merupakan sektor basis aktivitas ekonomi digunakan alat analisis dan memiliki potensi untuk dikembangkan. Location Quotient (LQ). Analisis Location Sektor tersebut antara lain adalah sektor Quotient (LQ) merupakan suatu analisis yang pertanian, industri pengolahan, pengadaan air, digunakan untuk mengetahui sejauh mana konstruksi, perdagangan besar dan jasa lainnya. tingkat spesialisasi sektor-sektor ekonomi Pada Tabel 5 dapat diketahui klasifikasi di suatu wilayah yang memanfaatkan sektor industri kecil berdasarkan pertumbuhan dan basis atau leading sektor. Location Quotient kontribusi. Kuadran I: Sektor maju dan tumbuh menggunakan perbandingan tentang besarnya dengan pesat. Sektor yang dikategorikan

Tabel 4.

\section{Perbandingan Besarnya Peranan Suatu Sektor/Industri di Kabupaten Malang Terhadap Besarnya Peranan Sektor/Industri Pada Provinsi Jawa Timur}

\begin{tabular}{clcc}
\hline \multirow{2}{*}{ No } & \multicolumn{1}{c}{ SEKTOR EKONOMI } & \multicolumn{2}{c}{ LQ } \\
\cline { 3 - 4 } & & 1,44 & Kabupaten Malang \\
\hline 1. & Pertanian & 0,36 & Basis \\
2. & Pertambangan & 1,03 & Non Basis \\
3. & Industri Pengolahan & 0,31 & Basis \\
4. & Pengadaan Listrik & 1,04 & Non Basis \\
5. & Pengadaan Air & 1,30 & Basis \\
6. & Konstruksi & 1,07 & Basis \\
7. & Perdagangan Besar & 0,39 & Basis \\
8. & Transportasi & 0,63 & Non Basis \\
9. & Penyediaan Akomodasi & 0,88 & Non Basis \\
10. & Informasi dan Komunikasi & 0,62 & Non Basis \\
11. & Jasa Keuangan & 0,86 & Non Basis \\
13. & Real Estate & 0,49 & Non Basis \\
14. & Jasa Perusahaan & 0,81 & Non Basis \\
15. & Administrasi Pemerintah & 0,92 & Non Basis \\
16. & Jasa Pendidikan & 0,89 & Non Basis \\
17. & Jasa Kesehatan & 1,44 & Non Basis \\
18. & Jasa Lainnya & & Basis \\
\hline
\end{tabular}


Tabel 5.

Klasifikasi Industri Kecil Berdasarkan Pertumbuhan dan Kontribusi: Typology Klassen

\begin{tabular}{|c|c|c|}
\hline \multirow{2}{*}{$\begin{array}{l}\text { Kontribusi } \\
\text { Sektoral }\end{array}$} & \multicolumn{2}{|c|}{ Pertumbuhan Sektoral } \\
\hline & gi $>=g$ & $\mathbf{g i}<\mathbf{g}$ \\
\hline $\mathbf{s i}>=s$ & $\begin{array}{l}\text { Kuadran I } \\
\text { Sektor Maju dan Tumbuh } \\
\text { dengan pesat } \\
\text { Pertanian } \\
\text { Industri Pengolahan } \\
\text { Jasa Lainnya } \\
\end{array}$ & $\begin{array}{l}\text { Kuadran II } \\
\text { Sektor maju tapi tertekan } \\
\text { Pengadaan Air } \\
\text { Konstruksi } \\
\text { Perdagangan Besar }\end{array}$ \\
\hline $\mathbf{s i}<\mathbf{g}$ & $\begin{array}{l}\text { Kuadran III } \\
\text { Sektor potensial atau masih } \\
\text { dapat berkembang dengan } \\
\text { pesat } \\
\text { Pengadaan Listrik } \\
\text { Transportasi } \\
\text { Jasa Keuangan } \\
\text { Real Estate } \\
\text { Jasa Perusahaan } \\
\text { Administrasi Pemerintah } \\
\text { Jasa Pendidikan }\end{array}$ & $\begin{array}{l}\text { Kuadran IV } \\
\text { Sektor relatif tertinggal } \\
\text { Pertambangan } \\
\text { Penyediaan Akomodasi } \\
\text { Informasi dan Komunikasi } \\
\text { Jasa Kesehatan }\end{array}$ \\
\hline
\end{tabular}

Sumber: Data Diolah 2020

dalam kuadran ini adalah Pertanian, industri Kuadran IV : Sektor relatif tertinggal antara pengolahan dan jasa lainnya. Kuadran II lain Pertambangan, Penyediaan Akomodasi, : Sektor yang masuk dalam kategori maju Informasi dan Komunikasi, Jasa Kesehatan. tapi tertekan antara lain Pengadaan Air, Strategi Pengembangan Ekonomi Konstruksi, Perdagangan Besar. Kuadran III : Lokal di Kabupaten Malang. Hasil analisis Sektor potensial atau masih dapat berkembang LQ menunjukkan bahwa sektor pertanian, dengan pesat antara lain Pengadaan Listrik, industri pengolahan, pengadaan air, kontruksi, Transportasi, Jasa Keuangan, Real Estate, perdagangan besar dan jasa lainnya merupakan Jasa Perusahaan, Administrasi Pemerintah, sektor basis yang dapat dikembangkan sebagai Jasa Pendidikan. Kuadran III : Sektor potensial sektor dalam pengembangan ekonomi lokal. atau masih dapat berkembang dengan pesat Hasil ini juga didukung oleh hasil dari analisis antara lain Pengadaan Listrik, Transportasi, tipologi klassen yang menyatakan bahwa Jasa Keuangan, Real Estate, Jasa Perusahaan, Pertanian, industri pengolahan dan jasa lainnya Administrasi Pemerintah, Jasa Pendidikan. masuk dalam kuadran I dan Pengadaan Air, 
Konstruksi, Perdagangan Besar masuk dalam kuadran II.

Sektor-sektor tersebut yang menjadi sektor unggulan dan dapat digunakan sebagai bentuk usaha kecil menengah dalam rangka pengembangan ekonomi lokal. Sebenarnya UKM pada Kabupaten Malang sudah mengalami perkembangan yang cukup baik. Akan tetapi para pelaku usaha masih mengalami kesulitan dalam beberapa hal dalam melaksanakan dan mengembangkan usahanya, diantaranya ada pada masalah perkembangan teknologi, modal dan mitra dengan usaha lain dalam mengembangan usaha. Hal ini sebenarnya bisa diwujudkan dengan cara berinvestasi. Guna mewujudkan iklim investasi yang baik maka perlu didukung, mengingat investasi memiliki peran penting dalam meningkatkan pertumbuhan perekonomian Kabupaten Malang. Salah satu hal yang bisa dilakukan adalah menyediakan informasi tentang peta potensi investasi, pemberian bantuan/intensif, memudahkan dalam memberikan perizinan dengan mudah dan transparan serta menyediakan kawasan industri.

Selain itu strategi lain dalam pengembangan UKM di Kabupaten Malang adalah memberikan pelatihan atau pembinaan dalam rangka mengembangkan ketrampilan para SDM, memberikan bantuan berupa peralatan dan juga membantu dalam memasarkan melalui promosi. Salah satu contohnya pada sektor pertanian, Masyarakat Kabupaten Malang perlu melakukan transformasi dari pola produksi dan cara berpikir agraris subsisten menuju pada cara berpikir ekonomis yang industrialis progresif. Artinya, aktifitas ekonomi baik itu disektor pertanian, perikanan dan kelautan, tidak hanya dipergunakan untuk memenuhi kebutuhan dasar rumah tangganya saja, akan tetapi ada strategi untuk memperbesar dan mengembangkannya sebagai sebuah potensi dan kekayaan ekonomi daerah yang dapat bersaing baik secara nasional maupun internasional. Untuk melaksanakan hal ini maka diperlukan pengkayaan inovasi melalui penerapan teknologi tepat guna dan pembinaan manajemen agrobisnis dan penguatan kelompok tani/usaha, selain itu juga memberikan pelatihan atau pembinaan dalam rangka mengembangkan ketrampilan para SDM, memberikan bantuan berupa peralatan dan juga membantu dalam memasarkan melalui promosi.

\section{SIMPULAN DAN SARAN}

Berdasarkan hasil penelitian mengenai pengembangan ekonomi lokal pada Kabupaten 
Malang diperoleh hasil bahwa pada analisis kontribusi, Kelompok Industri Kecil yang memiliki kontribusi terbesar berada pada kelompok UKM dari sektor industri pengolahan sebesar 29,48\%, perdagangan besar sebesar $19,5 \%$, pertanian sebesar $17,3 \%$ dan konstruksi sebesar $12,03 \%$. Dilanjutkan dengan analisis Location Quotient yang memiliki enam sektor nilai LQ lebih dari 1 yang artinya merupakan sektor basis dan memiliki potensi untuk dikembangkan. Sektor tersebut antara lain adalah sektor pertanian, industri pengolahan, pengadaan air, konstruksi, perdagangan besar dan jasa lainnya. Oleh karena itu beberapa strategi yang dapat dilakukan adalah antara lain menyediakan informasi tentang peta potensi investasi, pemberian bantuan maupun intensif, memudahkan dalam memberikan perizinan dengan aman dan transparan serta menyediakan kawasan industri.

Kelemahan pada penelitian ini adalah hanya berfokus pada strategi sektor maju. Saran yang dapat diberikan berdasarkan hasil penelitian yaitu Sektor UKM yang potensial perlu didukung dengan penyediaan kawasan industri serta infrastuktur yang baik, sehingga pemasaran hasil produksinya dapat meningkat.
Selain itu peran dan kebijakan pemerintah daerah sangat menentukan pengembangan UKM sehingga diharapkan pemerintah daerah dapat melindungi UKM dengan meningkatkan efisiensi dan produktivitas. Serta saran untuk peneliti selanjutnya agar lebih berfokus pada pengembangan tiap-tiap sektor, baik sektor maju, maupun sektor yang tertinggal.

\section{REFERENSI}

Badan Perencana Pembangunan Nasional. (2004b). Panduan Pembangunan Klaster Industri Untuk Pengembangan Ekonomi Daerah Berdaya Saing Tinggi, Jakarta: Direktorat Pengembangan Kawasan Khusus dan Tertinggal Bappenas.

Badan Perencana Pembangunan Nasional. (2005). Mengenal Klaster, Jakarta: Direktorat Pengembangan Kawasan Khusus dan Tertinggal Bappenas

Endi, Rizal (2015) Analisis Sektor Unggulan Dan Pengembangan Wilayah Di Kota Bandar Lampung 2000-2012. Fakultas Ekonomi dan Bisnis, Universitas Lampung.

Jumiyanti, Kalzum, R. (2018). “Analisis Location Quotient dalam Penentuan Sektor Basis dan Non Basis di Kabupaten Gorontalo". Gorontalo Development Review. Vol 1 No.1 April 2018.

Lestari, Etty P. (2010). "Penguatan Ekonomi Industri Kecil Dan Menengah Melalui Platform Klaster Industri'. Dalam Jurnal Organisasi dan Manajemen, Volume 6, Nomor 2, 146-157 Universitas Terbuka

Mukhlis, Atiyatna, Dehannisa (2014). "Pengembangan Ekonomi Lokal Kota Palembang Melalui Kajian Potensi Klaster Industri Kecil: Pendekatan Tipology Klassen. Jurnal Ekonomi Pembangunan. Volume 12, No.2 hal: 67-80. 
Pratomo, Hendri. (2008). "Dinamika Perkembangan Klaster Industri Mebel Kayu Desa Bulakan, Sukoharjo".Tugas Akhir. Semarang: Fakultas Teknik UNDIP

Sukirno, Sadono. 2011. Makro Ekonomi Teori Pengantar Edisi Ketiga. Jakarta: Rajawali.

Sjafrizal, 2008. Ekonomi Regional, Teori dan Aplikasi, Baduose Media, Cetakan Pertama, Padang

Sjafrizal, 2016. Perencanaan Pembangunan Daerah dalam Era Otonomi, Jakarta : Rajawali Pers.

Tambunan. 2001. Transformasi Ekonomi di Indonesia Teori dan Penemuan Emperis. Salemba Empat. Jakarta.

Warpani, Suwardjoko. 2001. Analisis Kota dan Daerah, Penerbit ITB, Bandung 